\title{
Pendekatan Psikoterapi Islam dalam Menguruskan Tekanan Pesakit Kronik
}

\author{
Norhafizah Musa \\ Universiti Teknologi Malaysia, norhafizah.kl@utm.my \\ Che Zarrina $\mathrm{Sa}^{\text {'ari }}$ \\ Universiti Malaya, zarrina@um.edu.my \\ DOI: https://doi.org/10.22452/usuluddin.vol47no1.1
}

\begin{abstract}
Abstrak
Kanser payudara merupakan salah satu penyakit kronik yang sangat digeruni dalam kalangan wanita seluruh dunia. Ianya merupakan penyakit yang bukan sahaja memberi kesan kepada fizikal malah ianya mampu mempengaruhi keadaan jiwa dan emosi penghidap kanser payudara ke tahap yang sangat kritikal. Kebanyakan daripada mereka tidak dinafikan akan mengalami stres yang berpanjangan sepanjang menjalani rawatan mahupun melewati kehidupan seharian. Justeru, kajian berbentuk analisis kualitatif deskriptif ini bertujuan membincangkan bentuk-bentuk tekanan yang dialami oleh pesakit kanser payudara. Kajian ini juga mengkaji pendekatan psikoterapi Islam dalam mengurus tekanan yang dialami oleh pesakit kronik ini. Hasil kajian ini dapat merumuskan bahawa pendekatan psikoterapi Islam merujuk kepada perbahasan ulama terdahulu mampu membantu pesakit dalam mengurangkan tekanan atau stres yang dialami. Kajian ini diharapkan dapat menjadi satu panduan yang berguna kepada pesakit-pesakit yang mengalami masalah gangguan jiwa terutama kepada mereka yang menghidapi penyakit yang digeruni seperti pesakit kronik, iaitu kanser payudara.
\end{abstract}

Kata kunci: penyakit kronik, stres, psikoterapi Islam, spiritual, kesejahteraan

\section{Islamic Psychotherapy Approach in Stress Management of Chronic Patients}

\section{Abstract}

The research is about the discussion on the Islamic psychotherapy in order to overcome stress among chronic patients, which are, breast cancer patients. Breast cancer is one of the most undesirable diseases among women worldwide. The disease will affect the physical and also affect mood and emotion as well. Most of them will experience prolonged stress during treatment or even through everyday life. This descriptive qualitative analysis study aims to discuss forms of stress experienced by the patient. It also aims to examine this psychotherapy methods that become the main instrument in this study can reduce the stress 
experienced by patients. The results of this study can be concluded that the establishment of the Islamic module-based psychotherapy can help patients reduce stress. This study is expected to be a useful guide for patients suffering from mental disorders, especially to those who suffer from dreaded diseases like breast cancer patients.

Keywords: chronic disease, stress, Islamic psychotherapy, spiritual, well-being

\section{Pendahuluan}

Pesakit kronik adalah gangguan utama kepada sistem fizikal, namun kesannya kepada seluruh elemen kehidupan, seperti spiritual, psikologi, emosi dan juga psikososial seseorang individu. Dari segi fizikal, rawatan pakar di pusat perubatan telah banyak membuat kajian dan rawatan bagi membantu menyembuh penyakit yang dialami. Namun dari aspek lain juga perlu dibantu agar seseorang individu yang menghidapi penyakit tersebut mendapat perhatian dan rawatan bagi memastikan hidup seseorang itu berkualiti dan bermakna. Antara cadangan rawatan ialah melalui terapi psiko atau dinamakan psikoterapi. Psikoterapi didefinisikan sebagai cara pengubatan dengan menggunakan pengaruh doktor terhadap jiwa pesakit (penderita) tanpa menggunakan ubat-ubatan tetapi dengan kaedah cadangan, nasihat, menghibur, hipnosis dan sebagainya atau rawatan sakit jiwa atau gangguan mental dengan menggunakan kaedah psikologi. ${ }^{1}$ Psikoterapi penting kerana berdasarkan kajian-kajian tekanan yang dialami oleh seseorang lebih bersifat psikologi atau kejiwaan. $^{2}$

\section{Tekanan yang Dialami Pesakit Kronik}

Satu kajian berkaitan dengan tekanan yang dilalui oleh seorang pesakit kronik seperti kanser payudara ialah Association of Fatigue with Perceived Stress in Chinese Women with Early Stage Breast Cancer Awaiting Adjuvant Radiotherapy. Keletihan disebabkan kanser adalah biasa di kalangan wanita Cina yang

\footnotetext{
Dewan Bahasa dan Pustaka Brunei, Kamus Bahasa Melayu Nusantara, 2149.

2 Nuuferulla Kurniantyas Pangastiti dan Mudji Rahardjo, "Analisis Pengaruh Dukungan Sosial Keluarga Terhadap Burnout Pada Perawat Kesehatan di Rumah Sakit Jiwa (studi pada RSJ Prof Dr Soeroko Magelang)", (Tesis Kedoktoran, Universitas Diponegoro, 2011), 9-10.
} 
mengalami kanser payudara. Metodologi kajian ini mengunakan kajian keratan rentas untuk meneroka tekanan akibat daripada kebimbangan, kemurungan, sakit dan kualiti tidur. Kajian ini dilakukan ke atas 133 orang wanita Cina yang mengalami kanser payudara peringkat awal dan berusia di antara 25 tahun sehingga 68 tahun. Majoriti wanita ini telah selesai pembedahan dan kimoterapi dan sedang menunggu radioterapi. Soal selidik telah diedarkan untuk mengumpul data dan mendapati bahawa empat puluh lima peratus daripada wanita tersebut mengalami kepenatan yang teruk. Kajian ini penting untuk memantau psikologi pesakit akibat daripada kelemahan keadaan fizikal semasa rawatan dijalankan. ${ }^{3}$ Hal ini kerana semasa menjalani rawatan, pesakit merasa letih seterusnya menyebabkan pesakit tidak bersemangat untuk menjalani aktiviti harian. Keletihan tersebut juga mengakibatkan emosi pesakit tidak stabil. Keadaan ini menyebabkan pengurusan harian diri terganggu. ${ }^{4}$

Satu kajian yang telah dijalankan oleh Chiara Renzi et al bertajuk Stress Exposure in Significant Relationships Is Associated with Lymph Node Status in Breast Cancer menyatakan tekanan hidup yang berlaku kepada pesakit kanser payudara akan mempengaruhi kesihatan dan kehidupan pesakit. Dapatan kajian menunjukkan hubungan sentimental dan ikatan ibu bapa mempunyai peranan yang boleh memodulasi perkembangan kanser melalui tekanan psiko-fisiologi dan mempengaruhi sistem imun. ${ }^{5}$ Hubungan sentimental yang dibincangkan melibatkan hubungan kasih sayang, sikap prihatin serta ambil berat dalam kekeluargaan. Kajian tersebut membuktikan tekanan atau stres

3 Rainbow T. H. Ho, Tracy T. C. Kwan, Irene K. M. Cheung, et al, “Association of Fatigue with Perceived Stress in Chinese Women with Early Stage Breast Cancer Awaiting Adjuvant Radiotherapy”, Stress Health 31, (2015), 214-221.

4 Hofman, Maarten, Julie L. Ryan, Colmar D. Figueroa-Moseley, Pascal JeanPierre, dan Gary R. Morrow. "Cancer-related Fatigue: the Scale of the Problem", The Oncologist 12, no. Supplement 1 (2007), 4-10.

5 Chiara Renzi, Valeria Vadilonga dan Sara Gandini, "Stress Exposure in Significant Relationships is Associated with Lymph Node Status in Breast Cancer", Relational Stress in Breast Cancer, dicapai 24 Februari 2016, DOI:10.1371/journal.pone.0149443. 
dalam hubungan sentimental boleh menyebabkan kemerosotan pada sistem imun ${ }^{6}$.

Perceived cognitive impairment in Chinese patients with breast cancer and its relationship with post-traumatic stress disorder symptoms and fatigue adalah kajian laporan klinikal yang telah dijalankan oleh Jie $\mathrm{Li}$ et al mendapati bahawa kimoterapi mempunyai kesan negatif ke atas kognitif pesakit kanser payudara. Bukti mengenai kesan faktor-faktor psikologi seperti gejala gangguan stres post-trauma dalam menerima kemerosotan kognitif adalah terhad. Kajian ini mengkaji antara faktor-faktor psikologi dan kemerosotan kognitif yang diterima di kalangan pesakit kanser payudara. Secara keseluruhannya, 204 orang pesakit dinilai dan diuji dari sudut kemerosotan kognitif yang diterima, gejala gangguan stres post-trauma, keletihan, kebimbangan dan kemurungan berdasarkan ukuran dalam laporan diri. Regresi linear hierarki telah dijalankan untuk mengkaji perkaitan antara pembolehubah dengan kemerosotan kognitif. Berdasarkan kajian tersebut pengkaji membuat kesimpulan bahawa selain daripada kimoterapi, gejala gangguan stres post-trauma terutama hyperarousal iaitu situasi kesakitan yang menyebabkan seseorang sudah tidak mampu tanggung seterusnya memberi kesan kepada psikologi dan fisiologi ${ }^{7}$, dan seterusnya keletihan merupakan faktor yang penting dalam kemerosotan kognitif dan siasatan lanjut perlu dijalankan ke atas kajian ini ${ }^{8}$.

Sebuah kajian yang mengukur skala tekanan ialah Measuring reliability and validity of a newly developed stress instrument: Newly Diagnosed Breast Cancer Stress Scale. Kajian ini bertujuan untuk menilai kebolehpercayaan dan kesahan instrumen yang dibangunkan. Menurut kajian, pesakit kanser payudara ini jelas kelihatan susah, bimbang dan murung. Ianya membawa kepada miskin psikososial dan memberi kesan kepada penurunan kualiti

6 Chiara Renzi, Valeria Vadilonga, Sara Gandini, "Stress Exposure in Significant Relationships is Associated with Lymph Node Status in Breast Cancer, 8.

7 Entri "hyperarousal", laman sesawang The Free Dictionary, dicapai 15 Ogos 2018, https://medical-dictionary.thefreedictionary.com/hyperarousal.

8 Jie Li, Lixiang Yu, Zhouting Long et al, "Perceived Cognitive Impairment in Chinese Patients with Breast Cancer and its Relationship with Post-Traumatic Stress Disorder Symptoms and Fatigue", Psycho-Oncology 24 (2008), 676682. DOI: $10.1002 /$ pon. 
hidup kerana sukar mengurus tekanan, menyebabkannya menjadi semakin teruk. Kesahan kandungan kajian ini ditentukan oleh pakar kajian. Seramai 125 orang wanita yang disahkan menghidap kanser payudara telah ditemuramah sehari sebelum pembedahan payudara dilakukan. Hasil kajian menunjukkan Newly Diagnosed Breast Cancer Stress Scale mempunyai kebolehpercayaan yang boleh diterima dan kesahihan baik untuk mengukur tekanan pada pesakit yang baru didiagnosis dengan kanser payudara. Kajian ini juga sesuai digunakan dalam bidang klinikal kerana Newly Diagnosed Breast Cancer Stress Scale ini boleh menyediakan instrumen untuk mengenal pasti tahap tekanan ketika diagnosis pesakit kanser payudara. ${ }^{9}$

Tahap tekanan perlu dikenalpasti bagi memastikan kondisi pesakit dalam keadaan baik sebelum pembedahan dan selepas pembedahan. Hal ini penting untuk menjamin kualiti hidup pesakit tersebut agar lebih baik selepas pembedahan. Tekanan mesti dielakkan kerana memberi kesan negative kepada kualiti hidup pesakit dan melambatkan proses penyembuhan selepas pembedahan. Tekanan dan stres adalah suatu situasi yang sangat berkait dan boleh menganggu kualiti hidup harian pesakit. ${ }^{10}$

Stres merupakan suatu keadaan yang memberi tekanan jiwa atau mental seseorang. Ungkapan gambaran stres secara umumnya adalah tentang tekanan perasaan seseorang sehingga membuatkannya tidak mampu untuk menjalani kehidupan seperti biasa. ${ }^{11}$ Stres juga adalah satu fitrah bagi manusia iaitu keadaan yang pasti berlaku dalam diri manusia terutama bagi mereka yang menghadapi penyakit yang sukar diubati. Ini kerana fitrah kejadian manusia itu sendiri yang terdiri daripada sistem saraf dan unsur kimia yang boleh menyebabkan perasaan, mental dan jasmani manusia terpengaruh. Di dalam al-Qur'an, manusia mengalami tekanan perasaan atau emosi adalah disebabkan oleh faktor biologi

9 Tso-Ying Lee, Hsing-Hsia Chen, Mei-Ling Yeh, "Measuring Reliability and Validity of a Newly Developed Stress Instrument: Newly Diagnosed Breast Cancer Stress Scale”, Journal of Clinical Nursing 22 (2013), 2417-2425, Doi: 10.1111/jocn.12107.

10 Hofman, Maarten, Julie L. Ryan, Colmar D. Figueroa-Moseley, Pascal JeanPierre, and Gary R. Morrow. "Cancer-related Fatigue: the Scale of the Problem, 4-10."

11 Mohammad Zaini Yahaya dan Mohd Sukki Othman, Mengurus Stres: Islam Ada Caranya (Selangor: Soul Excellent Training \& Consultancy, 2010), 5. 
atau fitrah kejadian manusia itu sendiri. Allah SWT menjelaskan dalam firman-Nya:

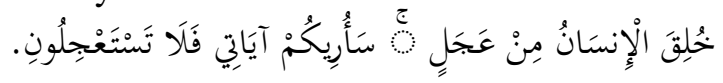

Al-'Anbiyā' 21: 37

Terjemahan: "Manusia telah dijadikan (bertabiat) tergesagesa. Kelak akan Aku perlihatkan kepadamu tanda-tanda (azab)-Ku; maka, janganlah kamu minta kepadaKu mendatangkannya dengan segera”.

FimanNya lagi dalam Surah al-Ma‘ārij, ayat 19-22:

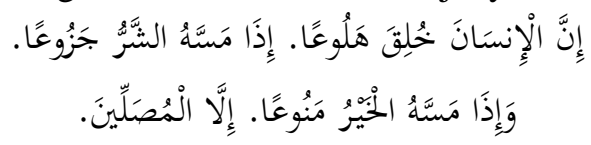

Al-Maeāij 70: 19-22

Terjemahan: "Sesungguhnya manusia itu diciptakan bersifat gelisah lagi kikir. Apabila ia ditimpa kesusahan ia berkeluh kesah. Dan apabila ia mendapat kebaikan ia amat kikir. Kecuali orang-orang yang mengerjakan solat".

Ayat al-Qur'an tersebut memberi gambaran sikap manusia yang akan menjadi keluh kesah dan kebimbangan apabila diuji dengan sesuatu musibah, seolah-olah tiada jalan keluar dari masalah tersebut. Namun, ayat yang terakhir dari surah al-Ma'ārij menceritakan bahawa masalah kebimbangan tersebut hanya boleh dihadapi dengan tenang oleh orang yang beriman ${ }^{12}$ :

Dalam Islam setiap dugaan yang datang adalah ujian daripada Allah SWT untuk meninggikan darjat dan martabat seseorang hamba di sisiNya. Semakin berat ujian atau tekanan yang dihadapi semakin besarlah pahala yang akan diperolehi. Oleh itu setiap manusia akan diuji bagi mendapat sebaik-baik ganjaran iaitu menikmati syurga Allah SWT ${ }^{13}$.

Apabila seseorang manusia itu berhadapan dengan sesuatu ujian dan bersabar dalam menempuhinya, tidak berputus asa atau berkeluh kesah, berfikiran positif dengan memahami bahawa

12 “Sayyid Qutb”, Terjemahan Tafsir fì Zilālil Qur'an, Surah al-Ma’ārij, laman sesawang Tafsir fi Zilalil Quran, dicapai pada 16 Ogos 2018, https://tafsirzilal .files.wordpress.com/2015/04/al-maarij-melayu.pdf.

13 Norfadilah Abdul Rahman dan Zakaria Stapa. "Pembangunan Kerohanian Berasaskan Al-Muhasibi dalam Menangani Gejala Sosial Masa Kini", (Proceeding of the International Conference on World Conference of Integration Knowledge, Bandung, Indonesia, 15-16 September 2014), 69. 
kesemuanya itu adalah dengan qadha' Allah SWT dan taqdirNya. Seseorang itu akan redha dan tenang jiwanya terhadap musibah yang menimpanya itu. Allah SWT tidak akan sia-siakannya malah ia akan memperolehi pertolongan Allah SWT bagi menyingkap segala kebimbangan dan keresahan yang membelenggunya selama ini serta Allah SWT akan selamatkannya daripada kesedihan. ${ }^{14}$ Allah SWT berfirman dalam sūrah al-Baqarah, ayat 214:

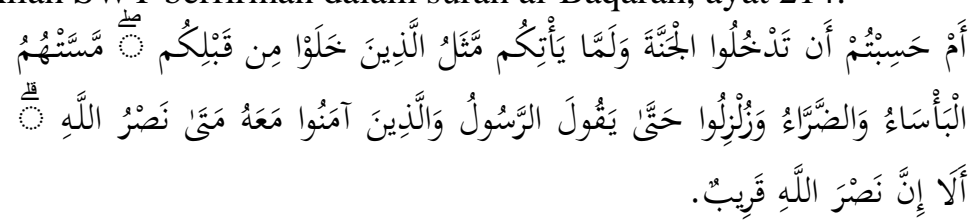

Al-Baqarah 2: 214

Terjemahan: "Apakah kamu mengira bahawa kamu akan masuk syurga padahal belum datang kepadamu (cubaan) sebagaimana halnya orang-orang terdahulu sebelum kamu? Mereka ditimpa malapetaka dan kesengsaraan, serta digoncangkan (dengan bermacam-macam cubaan) sehingga berkatalah Rasul dan orang-orang yang beriman bersamanya: "Bilakah datangnya pertolongan Allah?" Ingatlah, sesungguhnya pertolongan Allah itu amat dekat".

Ayat tersebut mengandungi makna bahawa manusia yang punyai iman yang kuat dia akan cekal menghadapi setiap ujian hidup. Manakala orang yang lemah imannya akan mudah mengalami tekanan jiwa. Tambahan lagi golongan yang lemah imannya memiliki sifat mudah kehilangan kepercayaan diri dan selalu berburuk sangka kepada Allah SWT dan orang lain. Bahkan kesan daripada pemikiran negatif ini dapat mengundang keburukan, kejahatan dan penyakit yang berbahaya ${ }^{15}$.

Selain itu, stres juga merupakan ujian dari Allah SWT yang bertujuan untuk menutup atau menghapuskan dosa-dosa hambaNya (kaffarah). Ini merupakan satu hikmah (rahsia) di sebalik ujian Allah dan seorang muslim yang mengetahui

14 Mustafa Al-Bugha dan Muhyiddin Misto, Al-Wafi Syarah Hadith 40 Imam Nawawi, terj. Ahmad Khairi Al-Latifi dan Noraine Abu (Kuala Lumpur: AlHidayah Publishers., 2007), 250.

15 Ade Tis'a Subarata, "Perspektif al-Quran tentang Musibah "Telaah Tafsir Tematik tentang Ayat-ayat Musibah" (Disertasi, Universitas Islam Negeri Syarif Hidayatullah, 2011), 4. 
tentangnya pasti akan memiliki kekuatan mental yang tinggi. Berbeza dengan mereka yang melihatnya secara zahir sahaja. Kekuatan mentalnya sangat lemah dan senang berkeluh-kesah atas segala musibah yang menimpa. Sabda Nabi SAW dalam sebuah hadis:

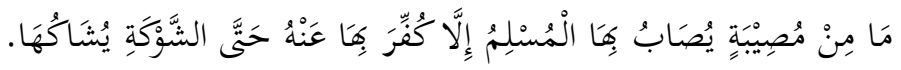

Terjemahan: "Tiada kesusahan yang ditimpakan ke atas seorang muslim melainkan Allah SWT menghapuskan (dosanya), walaupun (kesusahan itu hanyalah) duri yang mengenainya". ${ }^{16}$

Sabda Nabi SAW dalam hadis yang lain,

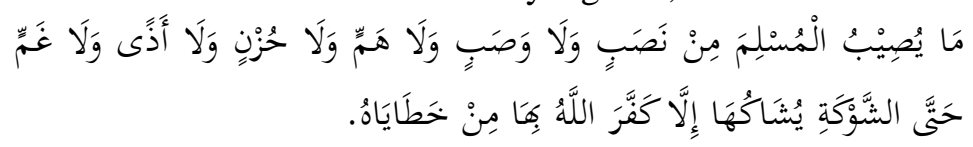

Terjemahan: "Apa jua yang menimpa diri seorang mukmin dari kepayahan, kesakitan, kesusahan dan apa pun keresahan yang dirasakannya, melainkan Allah SWT akan menghapuskan sebahagian dari kesalahan-kesalahannya". ${ }^{17}$

Maka setiap mukmin perlu bersedia untuk menghadapi tekanan dalam kehidupan dari segala sudut sama ada dari sudut mental atau fizikal. Malah mereka seharusnya memiliki kekuatan aqidah yang kukuh seperti keimanan kepada qad̄a' dan qadar yang akan menjadikan seseorang itu tabah menghadapi segalanya serta tidak mudah berputus asa dalam meneruskan kehidupan. Mereka juga wajib percaya bahawa sesungguhnya sesuatu itu datang daripada Allah dan akan kembali jua kepadaNya ${ }^{18}$.

Dari perspektif Islam, stres boleh dilihat sebagai salah satu fenomena 'penyakit jiwa' yang mempunyai kaitan erat dengan alnafs iaitu melibatkan aspek akal, roh, hati dan nafsu. Stres dapat mendatangkan pelbagai penyakit jiwa seperti gelisah, bimbang, runsing, sedih, murung yang keterlaluan dan sebagainya. Jika stres

${ }^{16}$ Hadith riwayat al-Bukhārī, Hadith Nombor 5640. Lihat Muhammad bin Ismā‘̄il al-Bukhārī, Șah̄ịh al-Bukhārī li-Abì 'Abd Allāh Muhammad bin Ismā '̄̄l al-Bukhārī al-Ju'fì (Riyadh: Dār al-Salām, 1999), 999.

17 Muhammad bin Ismā‘̄il al-Bukhārī, Muhib al-Dīn Khāṭib, Muhammad Fū'ad 'Abd al-Bāqī, Al-Jāmi' al-Șah̄ḥ (Kaherah: al-Matba'ah al-Salafiyah, 1979) 23. Hadith nombor 5641

18 Zaenal Abidin, "Ketika Stress Beraksi Islam Punya Solusi”, Jurnal Dakwah dan Komunikasi 3 No 1 (2009), 148-166. 
berpanjangan, ia memungkinkan berlakunya tindak balas atau perlakuan di luar batas-batas norma dalam masyarakat, kadangkala di luar batasan ajaran agama, dan di luar batas akal yang waras ${ }^{19}$.

Stres atau tekanan ini sering dialami oleh orang yang sakit terutamanya mereka yang menderita penyakit yang kronik dan sukar untuk diubati. Islam tidak melihat punca stres itu dari tekanan mental semata-mata dan bahkan ianya berpunca daripada kecelaruan dan kelemahan hati (qalb), roh, nafsu dan $\mathrm{akal}^{20}$. Elemen ini sangat berkait rapat dengan elemen penjagaan asas keagamaan. Justeru, ianya menjadi wajib kerana menjaga agama adalah tingkat pertama dalam penjagaan maqasid Syariah. Seterusnya adalah menjaga nyawa juga menjadi tahap kedua maqasid Syariah yang wajib dijaga oleh setiap individu.

Cadangan utama dalam usaha untuk menjaga nyawa berdasarkan penjagaan elemen keagamaan adalah melalui pendekatan psikoterapi Islam atau juga dikenali sebagai pendekatan tasawuf. Perbincangan lanjut berkenaan pendekatan ini akan dihuraikan di bahagian seterusnya.

\section{Konsep Psikoterapi Islam}

Al-Ghazālī, Abū TTālib al-Makki, Ibn 'Ata' Allāh, al-Mawardī dan lain-lain ulama terdahulu banyak mendatangkan pelbagai cadangan bagi membantu rawatan jiwa. Hal ini menunjukkan masalah kejiwaan bukan suatu yang baru, bahkan ianya suatu masalah yang telah berlaku sejak dahulu lagi. Sebagai contoh, Abū Țalib al-Makkī membincangkan usaha untuk membangunkan kerohanian dan akhlak manusia yang dapat dikategorikan sebagai psikoterapi Islam dengan mendatangkan perbincangan mengenai peringkat dan maqamat tertentu seperti taubat, sabar, syukur dan lain-lain ${ }^{21}$.

Manakala Hairunas Rejab mengkaji tentang Psikoterapi Islam dan Pengaplikasiannya dalam Kesihatan Mental. Kajian ini membina kerangka teori dalam ilmu psikoterapi Islam di bawah

${ }^{19}$ Che Zarrina, "A Purification of Soul According to Sufis : A Study of AlGhazali's Theory,” Jurnal AFKAR, no.3 (2002), 100-101.

20 Siti Noorsyafenas Safe dan Ahmad Yunus Mohd Nor, "Pengurusan Stress Menurut Al-Quran dan Hadith," Jurnal al-Hikmah 8 (1) 2016, 3-18.

21 Sharifah Basirah Syed Muhsin dan Che Zarrina Sa'ari, Kaedah Psikoterapi Islam berdasarkan Konsep Maqamat Abu Talib al-Makki (Kuala Lumpur: Dewan Bahasa dan Pustaka, 2015). 
kerangka Psikoterapi Iman, Psikoterapi Ibadah dan Psikoterapi Tasawuf. Menurut Hairunas, psikoterapi Islam merupakan metod yang paling asas dalam mewujudkan kebahagiaan, kesihatan mental dan keperibadian Islam berasaskan keimanan dan ketaqwaan kepada Allah. Kajian ini turut menyarankan agar para pendakwah dan pengkaji dapat membuat kajian lanjutan gangguan mental seperti kemurungan, neurosis, tekanan dan psikosis sebagai usaha memahami perilaku beragama individu dan masyarakat ${ }^{22}$.

Satu kajian telah dijalankan di sebuah Pondok Pesantren di Indonesia di mana pengkaji meneliti dan menyelusuri cara atau metode yang digunakan oleh pengasas pondok pesantren itu sendiri iaitu KH. Hamdani Bakran Adz Dzaky dalam mengatasi masalah masyarakat sekeliling pondok pesantren itu terhadap hubungan individu sesama mereka juga hubungan dengan Pencipta, Allah SWT. Kajian ini mengkaji cara-cara mengatasi gangguan-gangguan kejiwaan dan teknik-teknik yang digunakan serta tahap-tahap perlaksanaan psikoterapi dengan menggunakan metode Sufistik ${ }^{23}$. Antara contoh terapi sufistik ialah berzikir, solat, berselawat, mendengar muzik dan lain-lain amalan yang mendekatkan diri kepada Allah ${ }^{24}$.

Sebuah kajian di institusi perlindungan Kompleks Dar Assaadah (KDS), Jalan Jambu Laut, Kampung Batu, Batu 5, Jalan Ipoh, Kuala Lumpur mengenal pasti keberkesanan modul psikospiritual Islam sebagai asas rawatan pemulihan akhlak di institusi perlindungan. Selain itu, objektif kajian ini adalah untuk membandingkan perubahan kelakuan, budaya hidup dan sikap penghuni sebelum dan selepas menjalani rawatan dan pemulihan berasaskan Islam di KDS. Kajian ini juga turut menilai keberkesanan modul psikospiritual yang diterapkan di KDS terhadap kesihatan mental penghuni institusi tersebut. Analisis perbezaan sikap digunakan untuk mengukur keberkesanan program yang dilaksanakan di KDS. Jika terdapat perbezaan ke arah lebih positif antara keadaan responden sebelum mengikuti

${ }^{22}$ Hairunas Rejab, "Psikoterapi Islam dan Pengaplikasiannya dalam Kesihatan Mental," (Tesis Kedoktoran, Universiti Malaya, 2006).

23 Drs. Untung Joko Basuki. M. Pd. I, "Psikoterapi Islam Melalui Metode Sufistik Mengatasi Gangguan Kejiwaan" (Laporan Penelitian, Yokyakarta, Fakultas Teknologi Industri Institut Sains dan Teknologi. AKPRIND, 2013).

24 M Amin Syukur, "Sufi Healing: Terapi dalam Literatur Tasawuf" 20, no. November (2012): 391-412. 
program pemulihan di KDS dengan selepasnya, penyelidik menyimpulkan bahawa program tersebut berjaya ${ }^{25}$.

Kesimpulannya, rawatan menggunakan pendekatan psikoterapi Islam bukanlah suatu yang baru dalam usaha membantu masalah yang berkaitan kejiwaan atau mental. Namun, satu modul khusus untuk membantu pesakit kronik dalam menguruskan tekanan yang dihadapi belum dihasilkan secara lengkap. Pesakit kronik di sini adalah lebih tertumpu kepada pesakit kanser payudara kerana ia merupakan pembunuh nombor satu bagi wanita di Malaysia yang mana telah menyebabkan pelbagai tekanan yang dialami oleh kaum wanita sama yang menghidapi penyakit tersebut mahupun tidak.

\section{Pendekatan Psikoterapi Islam}

Perbincangan ini tertumpu kepada beberapa tokoh ulama muktabar yang membincangkan berkenaan elemen tasawuf dan psikoterapi dalam usaha merawat masalah kejiwaan seperti Ibn 'Atā' Allāh, al-Mawardī, Ibn Khaldun, al-Ghazālī dan Ibn Qayyīm.

\section{Isqat Tadbīr al-'Uyūb Ibn 'Ațā' Allah dalam Terapi Kefahaman}

Ibn 'Ațā' Allah juga mengemukakan sepuluh kaedah isqat tadbìr $a l$-'Uyūb dalam mendepani cabaran hidup. Yang pertama, mengetahui Allah SWT mentadbir diri manusia seperti keadaan manusia masa bayi. Allah memberi kurniaan rezeki susu ibu pada ketika bayi kerana tiada gigi. Sebelum keadaan manusia di alam dunia manusia mengakui tentang ketuhanan Allah khususnya Allah maha mentadbir seperti firman Allah:

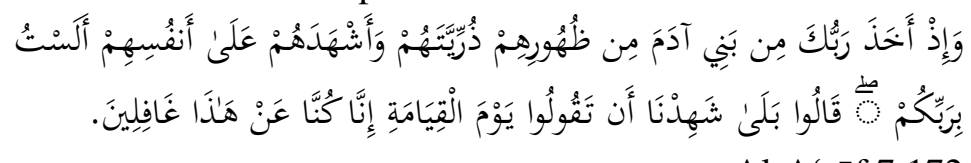

Al-A'rāf 7:172

Terjemahan: Dan (ingatlah wahai Muhammad) ketika

Tuhanmu mengeluarkan zuriat anak-anak Adam (turuntemurun) dari (tulang) belakang mereka, dan Ia jadikan

25 Khairul Hamimah Mohammad Jodi, Mohd Afifuddin Mohamad, dan Azizi Che Seman, "Penerapan Agama dalam Modul Psikospiritual dan Kesannya Terhadap Kesihatan Spiritual: Kajian Kes Kompleks Dar Assaadah Kuala Lumpur", Jurnal Syariah Malaysia (2014). 
mereka saksi terhadap diri mereka sendiri, (sambil Ia bertanya dengan firmanNya): "Bukankah Aku tuhan kamu?" Mereka semua menjawab: "Benar (Engkaulah Tuhan kami), kami menjadi saksi". Yang demikian supaya kamu tidak berkata pada hari kiamat kelak: "Sesungguhnya kami adalah lalai (tidak diberi peringatan) tentang (hakikat tauhid) ini".

Ini membuktikan Allah Ta'ala mentadbir alam sebelum ketiadaan diri manusia bahkan sebelum kewujudan nabi Adam a.s. Ibn 'Ațā' Allāh juga memberi penerangan tentang peta hidup manusia di muka bumi Allah bermula dari 'alam dzar sehinggalah ke padang mashyar samaada dimasukkan ke dalam syurga atau neraka. Keduanya, mengetahui bahawa diri jahil kerana suka tadbir mengikut nafsu dan tadbir daripada Allah adalah yang terbaik seperti firman Allah ${ }^{26}$.

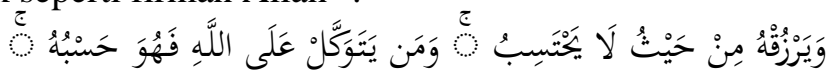

Al-Ṭalāq 65:3

Terjemahan: Dan (Ingatlah), sesiapa berserah diri bulat-bulat kepada Allah, maka Allah cukuplah baginya (untuk menolong dan menyelamatkannya).

Ketiga, mengetahui qadar dan qada' Allah Ta'ala bukan berlaku atas tadbir insan. Seperti yang pernah berlaku peristiwa yang datang bukan daripada tadbir diri dan haruslah diakui diri manusia bukan sepenuhnya boleh mentadbir sesuatu yang berlaku mengikut kehendak diri sendiri ${ }^{27}$.

Keempat, mengetahui Allah Ta'ala mentadbirkan dan memerintahkan langit dan bumi ${ }^{28}$.

$$
\text { وَمَا قَدَرُوا اللَّهَ حَقَّ قَدْرِه. }
$$

\begin{tabular}{llll} 
& & \multicolumn{2}{c}{ Al-An`ām`6:91 } \\
Terjemahan: Dan tiadalah mereka (kaum Yahudi) \\
menghormati \\
sebenarnya
\end{tabular}

Kelima, mengetahui Allah Ta'ala memilik diri manusia dan mengetahui manusia tidak dapat mentadbirkan diri sepenuhnya kerana di dalam milik Allah Ta`ala dan tiada kuasa dalam memilik makhluk yang dijadikan Allah Ta`ala. Sesuatu yang berada di

${ }^{26}$ Ibn 'Ațā' Allāḥ, al-Tanwīr fì Isqāt al-Tadbīr, 14-19.

${ }^{27}$ Ibn 'Ațā' Allāḥ, al-Tanwīr fì Isqāt al-Tadbīr, 14-19.

28 Ibn 'Ațā' Allāḥ, al-Tanwīr fì Isqāt al-Tadbīr, 14-19. 
tangan manusia hanyalah pinjaman daripada Allah dan bagaimana mungkin manusia dapat melawan Tuhan yang menjadikan makhluk $^{29}$.

Keenam, mengetahui bahawa berada dalam dunia kepunyaan Allah tidak memerlukan untuk bersusah payah seperti anologi yang dibawa oleh ibn 'Ațā' Allāh mengatakan tidak perlu susah payah dalam menyediakan makanan ketika berada di dalam rumah sebagai tetamu kerana telah disediakan oleh tuan rumah ${ }^{30}$.

Ketujuh, melihat kuasa dan qudrah Allah pada semua alam termasuklah pada diri manusia itu sendiri dan mengetahui Allah Ta`ala mentadbirkan dunia dan akhirat memberi rezeki di dalam dunia dan memberi pahala di dalam akhirat ${ }^{31}$.

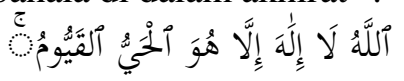

Al-Baqarah 2:255

Terjemahan: Allah, tiada Tuhan (yang berhak disembah) melainkan Dia, Yang Tetap hidup, Yang Kekal selamalamanya mentadbirkan (sekalian makhlukNya).

Kelapan, mengetahui bahawa Allah menyuruh untuk berbuat ibadah pada ketika hidup ${ }^{32}$.

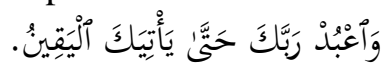

Al-Ḥijr 15:99

Terjemahan: Dan sembahlah Tuhanmu, sehingga datang kepadamu (perkara yang tetap) yakin.

Kesembilan, mengetahui bahawa diri berada dalam pemeliharaan Allah dan tidak perlu bersusah payah dalam memelihara diri kerana Allah memberi rezeki dan sebagai hamba hanya perlu membuat khidmat kepada Allah seperti firman Allah $^{33}$.

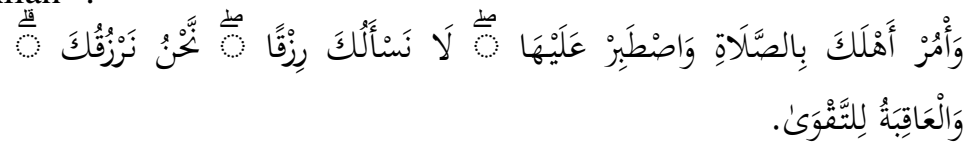

Taha 20:132

29 Ibn 'Ațā' Allāḥ, al-Tanwīr fì Isqāt al-Tadbīr, 14-19.

${ }^{30}$ Ibn 'Ațā' Allāh, al-Tanwīr fì Isqāt al-Tadbìr, 14-19.

31 Ibn 'Ațā' Allāḥ, al-Tanwīr fi Isqāt al-Tadbīr, 14-19.

${ }^{32}$ Ibn 'Ațā' Allāḥ, al-Tanwīr fì Isqāt al-Tadbīr, 14-19.

33 Ibn 'Ațā' Allāḥ, al-Tanwīr fì Isqāt al-Tadbīr, 14-19. 
Terjemahan: Dan perintahkanlah keluargamu serta umatmu mengerjakan sembahyang, dan hendaklah engkau tekun bersabar menunaikannya. Kami tidak meminta rezeki kepadamu, (bahkan) Kamilah yang memberi rezeki kepadamu.

Kesepuluh, mengetahui bahawa diri tidak mempunyai pengetahuan tentang pengakhiran sesuatu yang ditadbir. Contohnya, urusan yang disangka menjadi selamat tidak menjadi seperti jangkaan, sesuatu perkara disangka memberi kesenangan dan keuntungan akan tetapi mengalami kerugian manakala sesuatu yang disangka mendapat keburukan tetapi mendapat untung dan seperti mendapat manfaat daripada musuh dan dapat bala daripada orang yang dikasihi ${ }^{34}$. Firman Allah:

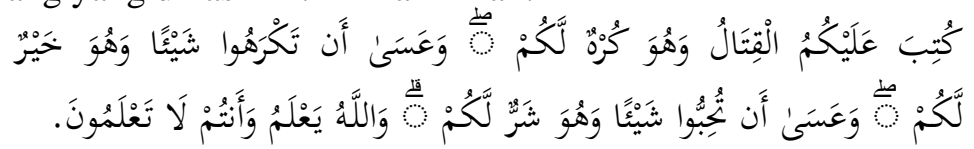

Al-Baqarah 2:216

Terjemahan: Kamu diwajibkan berperang (untuk menentang pencerobohan) sedang peperangan itu ialah perkara yang kamu benci; dan boleh jadi kamu benci kepada sesuatu padahal ia baik bagi kamu, dan boleh jadi kamu suka kepada sesuatu padahal ia buruk bagi kamu. Dan (ingatlah), Allah jualah Yang mengetahui (semuanya itu), sedang kamu tidak mengetahuinya.

Corak pemikiran ini mestilah diketahui oleh pesakit dalam mendekatkan diri dengan Allah SWT kerana idea ini memberi fahaman kepada pesakit untuk menjawab persoalan bagaimana seharusnya mereka meninggalkan tadbir yang buruk dan serah tadbir Allah tanpa mempertikaikan takdir dan tadbir insani.

Oleh yang demikian, pengkaji berpendapat apabila pesakit kanser payudara menguruskan tekanan dengan mengunakan kaedah Isqāt al-Tadbīr al-'Uyūb, pesakit akan berjiwa mutma'innah bersifat tama'ninah, tenang, tidak tertekan dan redha. Pengkaji juga mendapati dengan meninggalkan tadbir yang

34 Ibn 'Ațā' Allāh, al-Tanwīr fì Isqāt al-Tadbīr, 14-19. 'Uthmān Shihāb al-Dīn, Tanwīr al-Qulūb fì Isqāt Tadbìr al- 'Uyūb, 4. Lihat juga Nor Shakirah Binti Azizan, "Isqat Al-Tadbir dalam Kitab Tanwir Al-Qulub fi Isqat Tadbir Al'Uyub Terjemahan 'Uthman Shihab Al-Din Al-Funtiani”' (Akademi Pengajian Islam Universiti Malaya: Jabatan Akidah dan Pemikiran Islam, 2015), 172. 
buruk dan membatalkan kehendak nafsu seperti perasaan terlalu tidak sabar untuk pulih akan membuat pesakit lebih tenang kerana mengetahui dan memahami sesuatu itu mengikut tadbir Allah dan kehendak Allah SWT bukannya kehendak manusia. Pesakit akan mula menunjukkan penerimaan diri sebagai hamba dan bertawakal kepadaNya.

Teori ini membimbing manusia untuk menyakini bahawa Allah Ta`ala yang Maha Kuasa. Selain itu, seorang yang sentiasa ingat akan kekuasaan Allah akan merasai perlindungan daripada Allah. Seterusnya, manusia merasa redha dengan dapat menerima segala hukum, tadbir dan takdir daripada Allah. Oleh yang demikian apabila diaplikasikan teori ini pesakit mengetahui iradah Allah tidak dapat ditandingi oleh kehendak manusia.

Ibn 'Ațā' Allāh mengatakan bukti iman yang hakiki adalah menerima segala-gala hukum daripada Allah SWT dan Rasulullah SAW tanpa menuruti hawa nafsunya. Rasa keimanan ini menghasilkan impak bagi mengukuhkan hati untuk bersabar dengan apa yang telah berlaku, sedang berlaku dan akan berlaku dan mengambarkan manusia perlu mengawal kehendak hawa nafsu mereka mengikut apa yang disuruh oleh Allah serta menjauhi dan meninggalkan apa yang dilarangNya ${ }^{35}$.

Kemudian, hadirnya perasaan rasa sabar dalam hati ketika menghadapi takdir kerana mengetahui adanya pertolongan dan rahmat dari Allah Ta`ala serta tadbir dari Allah SWT adalah yang terbaik. Seseorang itu tidak mudah sombong dan terpedaya dengan tadbir dirinya sendiri kerana mengetahui ada tadbir Ilahi yang mengatasi segala kemampuan dan kekuatan diri. Ianya menjadi sumber kekuatan kepada manusia kerana yakin tadbir Ilahi dalam semua perkara yang telah berlaku sedang berlaku dan akan berlaku. Ini dapat menghasil kemanisan iman, rasa redha terhadap Allah dan Allah meredainya. Seseorang yang yakin dan percaya dengan kekuasaan Allah maka akan lahirlah tanda-tanda tiada kerisauan baginya ${ }^{36}$.

Modul pengurusan stres yang menggunakan konsep Isqāt Tadbìr al- 'Uyūb mampu mempengaruhi aspek sifat atau tingkah laku luaran manusia kerana bahagian luaran dan dalaman manusia

35 Ibn 'Ațā' Allāh, al-Tanwīr fì Isqāt al-Tadbīr, 12.

${ }^{36}$ Ibn 'Ațā' Allāḥ, al-Tanwīr fì Isqāt al-Tadbìr, 38. 
saling lengkap melengkapi dalam diri manusia ${ }^{37}$. Ini memberi sistem kepercayaan dalam diri pesakit yang mempraktikan Isqāt Tadbīr al-'Uyūb di dalam kehidupan seharian memiliki jiwa yang tenang mengikuti cara dan laluan jalan yang diredhai Allah.

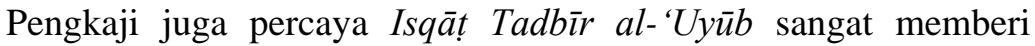
kesan bagi membentuk peribadi muslim yang diredhai berdasarkan teori yang diutarakan oleh Ibn 'Ațā' Allāh ${ }^{38}$.

Selain itu, pengkaji juga mendapati bahawa terdapat kajian yang pernah dilakukan menggunakan tiga dimensi iaitu kepercayaan beragama, perubahan niat positif (positive intentionality), perubahan kepada positif berkait rapat dengan terapi kefahaman ${ }^{39}$.

\section{Adab al-Riyādah wa al-Istislah al-Mawardī dalam Terapi Personaliti Karektor atau Behavior}

Rasulullah SAW merupakan utusan kepada manusia pada masa kini untuk menjadi contoh teladan dan ikutan berdasarkan keperibadian dan kesempurnaan akhlak beliau dalam menyeru manusia mengikut perintah Allah SWT dan meninggalkan larangannya ${ }^{40}$. Allah berfirman:

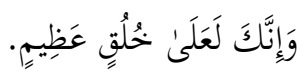

Al-Qalam 68:4

Terjemahan: Dan bahawa sesungguhnya engkau mempunyai akhlak yang amat mulia.

37 Ibn 'Ațā' Allāḥ, al-Tanwīr fì Isqāt al-Tadbīr, 38. Yatimah Sarmani dan Mohd Tajudin Minggal, Teori Kaunseling Al-Ghazali, Mengenal Ilmu, Sejarah dan Kandungan Al-Quran (Batu caves: PTS Publication, 2008), 28 \& 40.

38 Ibn 'Ațā' Allāḥ, al-Tanwìr fì Isqāt al-Tadbīr, 58.

39 DRS. H. Abdullah Hadziq, MA, "Psikologi Sufistik dan Humanistik: Studi Pemikiran Al Ghazali dan Abraham Maslow Serta Implikasinya bagi Pengembangan Pemikiran Psikologi" (Yogyakarta: Program Pascasarjana IAIN Sunan Kalijaga, 2004), 28. Lihat juga Khairul Hamimah Mohammad Jodi, Mohd Afifuddin Mohamad dan Azizi Che Seman. "Penerapan Agama dalam Modul Psikospiritual dan Kesannya Terhadap Kesihatan Spiritual: Kajian Kes Kompleks Dar Assaadah Kuala Lumpur", Jurnal Syariah Malaysia, 122.

40 Abī Ja'far Muhammad bin Jarīr al-Ṭabarī, Tafsīr al-Ṭabarī (Kaherah: Markaz al-Buhuth wa al-Dirāsāt al-'Arabiyyah al-Islāmiyyah, 2001), 23:150. 
Setiap individu mempunyai potensi untuk beramal dengan tingkah laku yang baik ${ }^{41}$. Dalam membentuk akhlak yang terpuji memerlukan kaedah mujāhadah dan riyā dah, perlu memperbaiki dan membina tingkah laku yang baik dari semasa ke semasa untuk meraih keredhaan Allah SWT bagi memastikan ketenangan dalam hidup ketika menghadapi cabaran dalam kehidupan memerlukan kesempurnaan tingkah laku yang baik dan tidak melanggar ketetapan perintah Allah ${ }^{42}$.

Terdapat dua bentuk dalam memperbaiki akhlak iaitu $a k h l \bar{a} q$ al-dhat dan af'äl al-irādah. Akhlāq al-dhat adalah tempat keluaran akhlak itu sendiri manakala af'âl al-irādah pula punca yang menimbulkan kehendak sesuatu faḍa' $\bar{l} l$ mahupun radha' $\bar{l} l$. Af'a $\bar{a} l$ al-irādah merupakan dorongan pembentukan fadà 'ìl melalui al'Aql dan $a l-R a$ 'y, dan pembentukan radhà' $\bar{l}$ melalui al-Hawā. Ini adalah proses yang berlaku ke atas setiap individu dan akhlāq alDhat dan af 'al al-Irādah mempunyai kaitan antara satu sama lain seperti pembahagian akhlak kepada gharizah dan muktasabah juga saling mempunyai perkaitan. Akhlāq gharizzah adalah akhlak yang wujud di dalam fitrah manusia. Akhlāq muktasabah pula terbentuk melalui jalan usaha akibat daripada kebiasaan yang dapat daripada pengalaman dan latihan.

Pembentukan akhlak melalui Adab al-Riyāg̣h wa al-Istislah menggunakan kaedah tazkīyah al-nafs dengan mengosongkan akhlak yang buruk dan mengamalkan akhlak yang baik. Himmah yang tinggi diperlukan bagi menganti akhlak yang buruk seperti sombong dan bangga diri kepada akhlak yang terpuji merendah diri kepada Allah, menahan kemarahan ${ }^{43}$.

41 Abū 'Alī Aḥmad ibn Muhammad ibn Ya'qūb Ibn Miskawayh, Tahdhīb alAkhlāq (Beirut: Dār Maktabah al-Hayāh, t.t.), 37-39. Wan Suhaimi Wan Abdullah dan Che Zarrina Sa'ari (eds.), "Tasawwuf dan Pembangunan Hakiki Ummah", Tasawwuf dan Ummah (Kuala Lumpur: Jabatan Akidah dan Pemikiran Islam, Akademi Pengajian Islam, 2004), 59-61.

42 Khalid Muhammad Khalid, Men Around the Messenger (Kuala Lumpur: Islamic Book Trust, 2005), 7. Abū Ḥāmid Muhammad Ibn Muhammad alGhazālī, Ihyā' 'Ulum al-Dīn (Beirut: Dār al-Kutub al-'Ilmiyyah, 2001), 3: 5153.

43 Abū Hasan 'Alī ibn Muhammad Al-Mawardī, Kitāb Adāb al-Dunyā wa al-Dīn (Beirut: Dār Maktabah al-Ḥayāh, 1986), 231. Lihat juga Siti Sarah Haji Ahmad, "Adāb al-Riyāḍah wa Al-Istislah dalam Pembangunan Modal Insan Menurut al-Mawardī dalam Karya Adāb al-Dunya wa al-Dīn" (Disertasi, Jabatan Akidah dan Pemikiran Islam, Universiti Malaya, 2014), 146. 
Al-Mawardī mengemukakan sepuluh sebab yang menyebabkan seseorang dapat mengawal kemarahannya iaitu mempunyai perasaan kasih dan sayang kepada orang jahil, berupaya dalam membantu, menjauhi celaan, tidak suka memperlekehkan kesilapan orang, malu dalam membantah suatu jawapan kerana kejahilan dirinya, mengawal diri untuk tidak memaki, berasa takut terhadap akibat dari suatu jawapan yang diberikan, memelihara kebaikan yang pernah dilakukan oleh orang lain dan pandai dalam mengambil peluang terhadap kesempatan yang tersembunyi ${ }^{44}$.

Tingkah laku yang terpelihara daripada kejahatan mempunyai kaitan dengan pembangunan kerohanian kerana dari dalaman jiwa manusia akan mengeluarkan tindakan manusia ${ }^{45}$. Tingkah laku yang baik melambangkan dekatnya diri seseorang dengan Tuhan kerana mempunyai rasa takut atau khawf kepada Allah SWT untuk berakhlak buruk sesama manusia ini melahirkan hubungan yang baik sesama manusia ${ }^{46}$. Memiliki tingkah laku yang baik akan menyebabkan individu tidak mengikuti hawa nafsu dan menahan diri daripada bersifat marah, bersyukur dalam menerima ketentuan Allah, tidak membenci musibah dan bersikap rasional berdasarkan ilham petunjuk yang diberikan oleh Allah untuk meninggalkan tingkah laku yang buruk ${ }^{47}$.

Kesempurnaan akhlak Nabi SAW mampu meninggalkan kesan ke dalam hati dan jiwa orang yang berada di sekelilingnya dan membina tingkah laku yang mulia seperti sabar, kasih sayang, lemah lembut dan sebagainya serta jauh daripada tingkah laku yang batil ${ }^{48}$. Contohnya, kisah seorang sahabat Nabi SAW iaitu Bilal bin Rabah yang mengalami kesusahan masih lagi mampu bersabar dan berpegang dengan konsep keimanan dan ketaqwaan

44 Siti Sarah, "Adāb al-Riyạ̣̄ah wa Al-Istislah dalam Pembangunan Modal Insan Menurut al-Mawardī dalam Karya Adāb al-Dunya wa al-Dīn”, 252.

45 Siti Sarah, "Adāb al-Riyāḍah wa Al-Istislah dalam Pembangunan Modal Insan Menurut al-Mawardī dalam Karya Adāb al-Dunya wa al-Dīn”, 233-234.

46 Siti Sarah, "Adāb al-Riyāḍah wa Al-Istislah dalam Pembangunan Modal Insan Menurut al-Mawardī dalam Karya Adāb al-Dunya wa al-Dīn”, 270.

47 Siti Sarah, "Adāb al-Riyāḍah wa Al-Istislah dalam Pembangunan Modal Insan Menurut al-Mawardī dalam Karya Adāb al-Dunya wa al-Dīn", 233.

48 Safī al-Raḥman al-Mubārakfurī, al-Rahiq al-Makhtum (Riyadh: Dār al-Salam li al-Nashr wa al-Tawzi', 2004), 494-497. Lihat juga Abī 'Abd al-Raḥman $\mathrm{Nu}$ 'man bin 'Abd al-Karīm, al-Watr al-Nabī Muhammad (Iskandariah: Dār alİmān, 2008), 35. 
kepada Allah sehingga berjaya di akhirat ${ }^{49}$. Individu yang memahami tentang terapi kefahaman yang berlandaskan tauhid, qadā' dan qadar, peta hidup, pandangan semesta dan makrifatullah mampu membentuk tingkah laku yang mengikuti jejak langkah Rasūllullāh SAW ${ }^{50}$.

Elemen yang ada dalam pendekatan yang dibawa oleh alMawardī ialah latihan hati agar boleh menjadikan hati kental dan tabah, serta subur dengan akhlak dan sifat-sifat mulia. Keadaan ini memerlukan kepada bimbingan dan latihan yang istiqamah sehingga melahirkan hati yang benar-benar teguh sehingga hanya mengharap kepada cinta dan pembalasan dari Ilahi.

\section{'Asabiyyah Ibn Khaldun dalam Terapi Ijtimā'ì}

'Asabiyyah ialah satu ikatan sosial persaudaraan bagi membentuk kekuatan jiwa setiap ahlinya ${ }^{51}$ dan merupakan unsur yang penting bagi membangunkan sikap saling tolong-menolong. Seterusnya, perkataan Ijtima $\bar{a} \mathfrak{l}$ bermaksud ilmu yang membahaskan tentang insan dan masyarakat ${ }^{52}$.

Insan menurut Ibn Khaldun adalah organisma yang bersifat hidup, berpeluang untuk berubah dan mencapai kemajuan sekiranya pelan pembangunan yang sistematik dapat dijalankan ${ }^{53}$. Jiwa individu boleh dipengaruhi oleh persekitaran. Sekiranya apabila individu berada dalam suasana persekitaran sosial yang baik dan harmoni, individu tersebut akan mengamalkan ajaran agama dengan kuat dan mampu membentuk keperibadian yang unggul $^{54}$.

49 Khālid Muhammad Khālid, Rijāl Hawl al-Rasūl (Kaherah: Dār al-Kutub alHadīthah. 1968), 118.

50 Syed Mohammad Hilmi Syed Abdul Rahman dan Che Zarrina Sa'ari, "Kesan Kefahaman Konsep Takdir Terhadap Pembangunan Modal Insan" Jurnal Usuluddin, bil. 27 (2008), 1-23.

51 Muhammad Mahmud Rabie', The Political Theory of Ibn Khaldun (Leiden: E. J. Brill, 1967), 165.

52 Muhammad ibn Mukarram ibn 'Alī ibn Ahmad Ibn Manzūr, Lisān al- 'Arab (Beirut: Dār Ihyā’ al-Turath al-'Arabī, 1999), 135.

53 Zaizul Ab. Rahman, Indriaty Ismail dan Khaidzir Ismail, "Strategi Modul Pembangunan Insan Seimbang Pengajian Agama (PISPA) Berdasarkan Teori Perubahan Sosial Ibnu Khaldun dalam Pengajian Agama di Universiti Kebangsaan Malaysia”, Jurnal Al-Hikmah, 6 (2) 2014: 43-52

54 Thouless, Robert H. "Experiments on paranormal guessing", British Journal of Psychology, British Psychological Society, 33, no. 1 (1942). 
Pergaulan sosial amat menitik beratkan hubungan sesama manusia termasuklah hubungan suami dan isteri, hubungan kejiranan, hubungan ibu bapa dan anak-anak, hubungan kemasyarakatan, serta hubungan antara pemimpin dan yang dipimpin. Hubungan ini mengandungi nilai-nilai akhlak yang baik berdasarkan perintah daripada Allah SWT untuk dijadikan amalan dalam kehidupan ${ }^{55}$. Manusia sering beinteraksi dengan kepelbagaian ciptaan Allah yang wujud di dunia termasuklah sesama manusia bagi memperolehi kebaikan bersama seperti firman Allah:

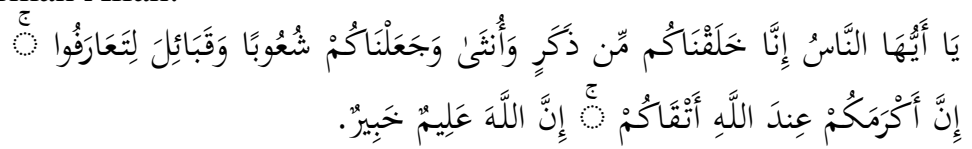

Al-Hujurāt 49:13

Terjemahan: Wahai umat manusia! Sesungguhnya Kami telah menciptakan kamu dari lelaki dan perempuan, dan Kami telah menjadikan kamu berbagai bangsa dan bersuku puak, supaya kamu berkenal-kenalan (dan beramah mesra antara satu dengan yang lain). Sesungguhnya semulia-mulia kamu di sisi Allah ialah orang yang lebih taqwanya di antara kamu, (bukan yang lebih keturunan atau bangsanya). Sesungguhnya Allah Maha Mengetahui, lagi Maha Mendalam PengetahuanNya (akan keadaan dan amalan kamu).

Bergaul dengan orang soleh boleh menyembuhkan penyakit rohani kerana mereka mempunyai hubungan yang baik dengan Allah SWT dan ketajaman batin. Setiap individu memerlukan pergaulan dengan individu lain dan masyarakat termasuklah untuk beribadat secara berjemaah, berkerjasama dalam masyarakat dan memenuhi kewajipan sesama muslim ${ }^{56}$. Pergaulan ini dapat menyatukan seluruh umatnya yang terdiri daripada pelbagai jenis bangsa, kaum, keturunan, dan warna kulit seperti mana firman Allah:

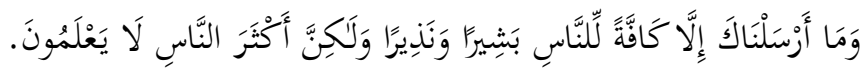

Saba' 34:28

55 Azizi Yahya, Psikologi Abnormal (Skudai: UTM Press, 2007), 200.

56 Jahid Sidek, Shaikh dalam ilmu Tariqah (Kuala Lumpur: Universiti Malaya, 1997) $21 \& 29$. 
Terjemahan: Dan tiadalah Kami mengutusmu (wahai Muhammad) melainkan untuk umat manusia seluruhnya, sebagai Rasul pembawa berita gembira (kepada orang-orang yang beriman), dan pemberi amaran (kepada orang-orang yang ingkar); akan tetapi kebanyakan manusia tidak mengetahui (hakikat itu).

Berkomunikasi dengan manusia adalah kaedah yang paling meninggalkan kesan ke atas individu ${ }^{57}$. Nabi Muhammad SAW sering kali berkomunikasi dengan para sahabat sehinggalah Baginda menjadi tauladan dan berperanan dalam memberi nasihat kepada para sahabat. Hubungan sosial ini memberi kesedaran kepada seorang untuk memahami dirinya sebagai hamba dan mengakui kekuasaan Allah $^{58}$. Hubungan ini melibatkan individu sebagai ahli dalam komuniti bertangungjawab kerja sosial kerana Allah dengan memerlukan pengorbanan jiwa, harta, tenaga, fizikal dan idea intelektual ${ }^{59}$. Menurut Ibn Khaldun, manusia mempunyai hubungan dengan persekitaran. Manusia hidup bermasyarakat dan memerlukan antara satu sama dengan lain serta kerap berhubung dengan orang yang dipercayainya bagi mendapat pandangan dan nasihat untuk mengurangkan tekanan dan menyelesaikan masalah. ${ }^{60}$

Interaksi yang berlaku di antara dua pihak dikenali juga sebagai kaunseling apabila salah seorang individu mempunyai masalah psikologi ${ }^{61}$. Proses interaksi ini bertujuan mengenali diri mengunakan daya keupayaan dan kemampuan yang dimiliki bagi

57 'Abd Allāh Nāsị̣ 'Ulwān, Kayf Yad'u al-Dā'iyyah (Beirut: Dār al-Salām, 1985), 45.

58 Zaizul Ab. Rahman, Indriaty Ismail dan Khaidzir Ismail, "Strategi Modul Pembangunan Insan Seimbang Pengajian Agama (PISPA) Berdasarkan Teori Perubahan Sosial Ibnu Khaldun dalam Pengajian Agama di Universiti Kebangsaan Malaysia”, 50.

59 Faridah Hj Hassan, "Ibn Khaldun and Jane Addams: The Real Father of Sociology and the Mother of Social Works", laman sesawang SiteSeer ${ }^{x}$ dicapai 20 Februari 2016, http://citeseerx.ist.psu.edu/viewdoc/download;jsessionid=B 117BA0DF1B3F19CD3CD43A90279DCAB?doi=10.1.1.510.3556\&rep=rep1 \&type $=$ pdf.

60 Zahran Ḥāmid 'Abd al-Salām, al-Tawjih wa Irshad al-Nafs (Kaherah: 'Alam al-Kutub, t.t), 29.

${ }^{61}$ Nik Asilah Nik Ali, "Rawatan Kaunseling Terhadap Penagih Dadah di Rumah Pengasih (Kuala Lumpur: Suatu Kajian Perbandingan dengan Islam”, (Kuala Lumpur: Universiti Malaya, 2002), 80. 
menyelesaikan tekanan masalah yang dialami ${ }^{62}$. Kemudian, Gibson menyatakan bahawa dalam membuat sesuatu keputusan yang diambil terdapat proses tolong menolong yang dikenali sebagai kaunseling ${ }^{63}$. Selain itu, proses diskusi yang menyeluruh bagi menyelesaikan masalah yang dihadapi juga disebut sebagai kaunseling ${ }^{64}$. Arthur J. Jones pula berpendapat tujuan kaunseling adalah untuk melahirkan individu yang boleh berdikari serta bertangungjawab dalam berdepan dengan masalah dalam kehidupan $^{65}$. Oleh yang demikian, pengkaji berpandangan bahawa untuk menyelesaikan masalah pesakit kanser payudara ialah dengan mengadakan kaunseling untuk berkomunikasi atau bergaul sosial. Ianya adalah sebahagian daripada modul psikoterapi Islam yang dinyatakan oleh pengkaji sebagai terapi ijtimā $\mathfrak{t}$.

Individu yang mempunyai hubungan interpersonal yang baik mempunyai emosi yang stabil dan mempunyai kesihatan jiwa yang sejahtera $^{66}$. Manakala individu yang mengalami gangguan jiwa menyebabkan kualiti dalam kehidupan berkurang, isolasi sosial dan skizofrenia. Pesakit yang mempunyai gangguan jiwa ini hilang keyakinan diri untuk bersama dengan keluarga dan masyarakat ${ }^{67}$. Ini menyebabkan fungsi keluarga semakin terhakis dan mendatangkan masalah seperti menghindari diri dalam $\operatorname{pergaulan}^{68}$.

Seterusnya, Pondok Pesantren Inabah Surabaya (PPIS) telah menggunakan konsep terapi penyedaran diri dengan berlandaskan pada ajaran Islam yang bersumber dari al-Qur'an, al-Sunnah

62 S. Mohamed Hatta, Psikologi dan Kaunseling Remaja (Selangor: Ummah Media Sdn. Bhd., 1994), 101.

63 Gibson, R.L dan Mitcheel M.H, Introduction to Guidance (New York: Michillan Publishing. Co. Inc. 1981), 7.

${ }^{64}$ Nik Asilah Binti Nik Ali, "Rawatan Kaunseling Terhadap Penagih Dadah di Rumah Pengasih Kuala Lumpur: Suatu Kajian Perbandingan dengan Islam”, 76.

65 Arthur J Jones, Principles of Guidance (New York: McGraw-Hill Book Company, 1970), 77.

${ }^{66}$ Sri Nyumirah, Pengaruh Terapi Perilaku Kognitif Terhadap Kemampuan Interaksi Sosial Klien Isolasi Sosial di RSJ DR Amino Gondohotumo Semarang (Indonesia: Universitas Indonesia Depok, 2012), 14.

${ }^{67}$ Sri Nyumirah, Pengaruh Terapi Perilaku Kognitif, 16.

68 Mohamad Kamil Abd Majid dan Rahimin Affandi Abd Rahim, "Perubahan Sosial dan Impaknya Terhadap Pembentukan Modal Insan Menurut Ibn Khaldun", Jurnal Hadhari 1 (2009), 45-76. 
Rasulullah SAW dan fatwa ulama, khususnya ajaran yang dikembangkan oleh Tarekat Qadiriyah wa Naqshabandiyah. Mursyid atau pembina sebagai ahli terapi memiliki kelayakan keilmuan, kecekapan, sikap keperibadian yang baik serta sanggup melaksanakan tugas dengan bersungguh serta mampu menjadikan dirinya sebagai ikutan atau mentor yang layak dicontohi atau mampu menjadi teladan yang baik (uswah hasanah).

Di antara proses terapi yang dilaksanakan di PPIS ialah pesakit diharapkan mampu menghubungkan diri atau bergaul dengan orang lain, bukan semata-mata menjaga dirinya sendiri sahaja akan tetapi menjadi individu yang dapat memahami keadaan persekitaran secara menyeluruh. Dalam keadaan ini, seorang pelatih akan merasakan adanya kesan altruistic sentiments iaitu perasaan senasib dalam proses terapeutik. Proses ini juga mampu menemukan mereka kepada nilai kehidupan (meaning) dan menyedarkan mereka tentang memiliki kekuatan yang saling memerlukan (primarily social beings) ${ }^{69}$.

Sehubungan dengan itu, pengkaji mengunakan kaedah ini dalam terapi ijtim $\bar{a} \mathfrak{c}$ sebagai satu pendekatan dalam menangani masalah yang dihadapi oleh umat Islam khususnya kepada pesakit kanser payudara. Berdasarkan kenyataan di atas dapat disimpulkan bahawa interaksi sesama manusia atau komunikasi dengan orang lain bertujuan untuk menolong dan membentuk pembinaan matlamat, perubahan positif dalam membuat keputusan bagi menguruskan tekanan dengan baik ${ }^{70}$. Pengkaji mendapati terapi ini telah diaplikasi oleh Rasulullahl SAW dengan memberi motivasi kepada para sahabat ${ }^{71}$.

\section{Tazkiyah al-Nafs al-Ghazālī dalam Terapi Amalan dan Penghayatan}

Penghayatan merupakan perlaksanaan agama di dalam kehidupan dari sudut akidah, ibadah dan akhlak berdasarkan kefahaman

69 Sri Astutik, "Psikoterapi Islami dalam Mengatasi Ketergantungan Narkoba di Pondok Pesantren Inabah Surabaya”, Program Doktor Pasca Sarjana ( IAIN Sunan Ampel, Surabaya, 2011).

70 Nik Asilah, "Rawatan Kaunseling Terhadap Penagih Dadah di Rumah Pengasih Kuala Lumpur”, 85.

71 Muhammad Yasin Mazhar, Organisasi Kepimpinan Rasulullah, terj Mohd Khalil Mad Zain dan Md Yusof Md Said (Kuala Lumpur: Dewan Bahasa dan Pustaka, 1993), 159. 
terhadap Islam. ${ }^{72}$ Amalan dan penghayatan adalah untuk mengabdikan diri kepada Allah $\mathrm{SWT}^{73}$. Melalui amalan dan penghayatan berlakunya pembersihan jiwa iaitu tazkiyah al nafs yang dapat merawat penyakit hati, memperelokkan ibadah dengan Allah $^{74}$, mengelak daripada perasaan gelisah di dalam hati dan menyebabkan individu dapat bersabar dengan segala yang berlaku ke atas diri $^{75}$. Kurang penghayatan kepada agama menyebabkan sukar untuk mencapai kebahagiaan hidup. Oleh yang demikian, pengkaji melihat amalan dan penghayatan mempunyai kaitan dengan psikoterapi. Pembinaan terapi ini membawa masyarakat kearah penghayatan untuk keluar daripada masalah yang dihadapi bagi mencapai kebahagian di dunia dan akhirat ${ }^{76}$.

Penghayatan dalam amalan penting bagi membentuk keperibadian yang mengikut al-Qur'an dan al-Hadith dan menghadapi kehidupan yang mencabar serta mengawal sifat peribadi yang negatif. Dengan mengerjakan amalan yang baik dapat mengatasi perasaan kebimbangan yang wujud dalam kecelaruan mental. ${ }^{77}$ Ibn Kathīr turut mengatakan bahawa orang yang mengerjakan solat akan diberi perlindungan Allah SWT dan diberikan taufiq dan hidayah serta mendapat termasuk di kalangan

${ }^{72}$ Mohamad Abu Bakar, Islam Sebagai Budaya dan Peradaban: Ke mana? Dimana?, Jurnal Pemikir 39\&40 (2005), 271-282.

73 Zulkiple Abd. Ghani dan Nor Salimah Abu Mansor, "Penghayatan Agama Sebagai Asas Pembangunan Pelajar: Analisis Terhadap Beberapa Pandangan Al-Imam Al-Ghazali", laman sesawang Universiti Teknologi Malaysia Institutional Repository, dicapai pada 20 Februari 2016, http://eprints.utm.my/ id/eprint/375/1/ZulkipleAbdGhani2006_Penghayatanagamasebagaiasaspembang unan.pdf.

74 Zulkiple Abd. Ghani dan Nor Salimah Abu Mansor, "Penghayatan Agama Sebagai Asas Pembangunan Pelajar, http://eprints.utm.my/id/eprint/375/1 /ZulkipleAbdGhani2006_Penghayatanagamasebagaiasaspembangunan.pdf.

75 Muhammad Uthman Najati, Psikoterapi Menurut al-Quran, terj Abd. Rahman, (Selangor: Human Resource Enterprise, 1992), 298.

76 Duane P Schultz dan Schultz Sydney Ellen, Theories of Personality (USA: ThomsonWadsworth, 2005) 314. Lihat juga Tony Buzan, The Power of Spiritual Intelligence (London :Thorsons, 2001) h.xiii. Rujuk, Khālid 'Abd alRaḥman, Tarbiyyah al-Abnā' wa al-Banāt fì Daw' al-Qur'ān wa al-Sunnah (Beirut: Dār al-Ma'rīfah, 2005), 178.

77 Abū Ḥāmid Muḥammad Ibn Muḥammad al-Ghazālī, Majmu'ah Rasā'il alImām al-Ghazālī, "Rawḍah al-Ṭālibīn wa "Umdah al-Sālikīn" (Beirut: Dār alKutub al-'Ilmiyyah, 1986), 2:109. Lihat juga Al-Mandili, Penawar Bagi Hati (Yala: Sahabat Press, 1964), 36-38. 
orang-orang yang tenang dan mendapat ketenangan hati ${ }^{78}$. Oleh yang demikian, orang yang mengerjakan amalan kerana beriman dengan memberi sepenuh keyakinan kepada Allah dan percaya dengan qad̄a'dan qadar dari Allah dapat mencegah dan merawat penyakit mental atau dalaman.

Antara tahap dalam tazkiyah al-nafs ialah takhallī, tahallī dan tajallī ini telah dibincangkan oleh Ibn 'Ața' Allāh dalam pendekatan Isqat Tadbir. Pendekatan ini juga telah dibincangkan oleh al-Ghazālī menunjukkan dalam usaha memperbaiki diri menjadi hamba yang lebih baik memerlukan kepada usaha dalam mencapai setiap tahap untuk lebih dekat dengan Allah SWT, seterusnya berakhlak dengan akhlak yang mulia dalam berhadapan dengan segala ujian kehidupan ${ }^{79}$.

Sebagai contoh, pesakit kanser akan merasa stres dan murung kerana rasa kecewa penyakit tersebut menimpa diri mereka. Sedangkan sekiranya mereka meletakkan elemen redha dengan takdir, dan menganggap ujian dari Allah SWT, justeru rasa sabar dan syukur dengan ujian akan lebih menghiasi diri.

Selain daripada pendekatan tazkiyah al-nafs, al-Ghazālī juga menekankan konsep bimbingan menerusi konsep al-irsyad dan alnafsiyy yang mana satu pendekatan yang berasingan yang dibawa oleh al-Ghazālī dalam penulisan-penulisannya. Konsep ini penting dalam usaha untuk mencapai tazkiyah al-nafs. Al-irsyad adalah bimbingan, manakala al-nafsiyy adalah bersifat spiritual dan kerohanian. Definisi bagi pendekatan ini adalah kaedah membimbing, mengajar dan menunjukkan cara untuk menuju ke arah kebaikan. Pendekatan ini telah dibincangkan oleh Salasiah Hanin Hamjah dan kajian kedoktorannya ${ }^{80}$. Pendekatan ini mencadangkan agar ada seorang guru untuk membimbing seseorang individu itu bagi memastikan mereka menjalankan amalan-amalan dengan betul dan lebih faham. Pendekatan ini

78 Al-Ghazali, Ihya' 'Ulum al-Din, Jilid 1. Terj.TK.H. Ismail Yakub. (Singapura: Pustaka Nasional, 1998), 1:509.

79 Masuriyati Yahya dan Che Zarrina Sa'ari, "Program Zikrullah dan Aktiviti Kerohanian Asas Pembangunan Spiritual Golongan Belia Perlu Perhatian (PP) dalam Merealisasikan Gagasan Negara Zikir Brunei Darussalam”, GJAT 6, no. 1 (2016): 109.

${ }^{80}$ Salasiah Hanin Hamjah, "Pendekatan Da wah Al-Irsyad Al-Nafsiyy Menurut Al-Ghazali: Satu Kajian di Pusat Kaunseling Majlis Agama Islam Negeri Sembilan" (Tesis Kedoktoran, Universiti Kebangsaan Malaysia, 2008). 
sesuai diaplikasikan dalam pesakit kanser payudara kerana apabila mereka dikesan mempunyai penyakit yang kritikal, mereka akan menjadi buntu dan memerlukan kepada tunjuk ajar dan nasihat daripada orang lain. Pendekatan ini sangat sesuai untuk diaplikasikan bagi membantu seorang pesakit kronik dalam usaha mereka untuk lebih dekat kepada Allah SWT dan redha dengan penyakit yang dihidapi mereka.

\section{Al-Shifä' Ibn Qayyim dalam Terapi Hati}

Al-Shifa ' bermaksud kesembuhan fizikal dan rohani $^{81}$. Ia juga merupakan gelaran atau sifat bagi al-Qur'an yang mana banyak menyebut tentang kesembuhan penyakit ${ }^{82}$. Al-Shifā' berkaitan dengan penyembuhan dari aspek fizikal seperti organ badan dan juga aspek dalaman seperti hawā, nafs, qalb dan 'aql. Al-Shifā' dalam terapi hati ialah dengan menggunakan kaedah membaca ayat al-Qur'an, berdoa dan berzikir ${ }^{83}$ dan dengan usaha ini diyakini mampu menyembuhkan pelbagai penyakit termasuklah perasaan sedih yang melampau ${ }^{84}$. Menurut Ibn Qayyīm juga konsep al-shifā' ialah memberikan satu penawar dalam aspek mendorong mencapai tingkah laku yang positif ${ }^{85}$. Sebagaimana firman Allah SWT dalam Surah al-Syu'arā' ayat 80:

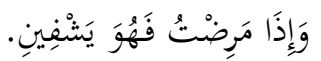

Al-Syu'ara' 26:80

Terjemahan: "Dan apabila aku sakit, maka Dia lah yang menyembuhkan penyakitku".

Terapi hati ini juga mendorong manusia menjalankan tugas sebagai hamba dan khalifah di muka bumi dengan sebaiknya dan

81 Aḥmad bin Muḥammad bin 'Alī al-Muqrī al-Fayyumī, al-Misbāh al-Munir, juzu' 2 (Beirut: al-Maktabah al-'Ilmiyyah, t.t.), 1:319.

82 Nurdeng Deuraseh, Preservation of Health in Islamic Law (Kuala Lumpur: International Islamic University Malaysia: IIUM Press, 2009), 15.

${ }^{83}$ Ibn Qayyīm al-Jawziyyah, Zād al-Ma'ād fì Hady Khayr al-'Ibād, tahqiq, takhrij dan ta'liq oleh Shu'ayb dan 'Abd al-Qādir al-Arnaūt (Beirut: Muassasah al-Risālah, dan Maktabat al-Manār al-Islāmiyyah, 1992 ), 4:177.

${ }^{84}$ Ibn Qayyīm, Zād al-Ma 'ād fì Hady Khayr al- 'Ibād, 4:352.

${ }^{85}$ Ibn Qayȳ̄m al-Jawziyyah, al-Da'wā aw al-Jawāb al-Kāfi li Man Sa'ala 'an al-Da 'wā' al-Shāfì (Mansourah: Dār al-Khulafā' li al-Nashr wa al-Tawzī', 1994), 10-11. 
mampu mempengaruhi tingkah laku individu ${ }^{86}$. Hal ini kerana hati yang baik dan terpimpin akan berlumba-lumba ke arah kebaikan untuk mencapai keredaan Allah $\mathrm{SWT}^{87}$. Hati insan yang dihinggap penyakit dalaman mestilah dirawat dengan bersungguh-sungguh untuk mendapat ganjaran kebaikan daripada Allah kerana hati yang mempunyai penyakit akan menyebabkan seluruh kehidupan termasuk aspek kesihatan akan terganggu ${ }^{88}$. Pembersihan hati yang dibuat dengan penuh keikhlasan akan dikurniakan rahmat daripada Allah ${ }^{89}$.

Terapi hati akan mencetuskan komunikasi dengan Allah SWT seterusnya membawa kepada kebahagiaan dunia dan akhirat ${ }^{90}$. Terapi hati juga dapat menghapuskan kesan buruk seperti dosa yang ada pada hati manusia dan menjauhkan diri daripada berkelakuan jahat ${ }^{91}$. Ibn Qayyīm menyatakan bahawa terapi hati merupakan cara terbaik untuk merawat gangguan jiwa seperti kesedihan, kemurungan dan segala penyakit hati yang timbul akibat daripada dosa kemaksiatan. Ini kerana terapi hati mampu memberi resolusi dalam menghadapi masalah tersebut melalui pelbagai cara, contohnya dengan memperbanyakkan bacaan ayat al-Qur'an, berzikir dan berdoa untuk memohon keampunan daripada Allah bagi menguatkan jiwa dan berasa tenang ${ }^{92}$.

\section{Penutup}

Berdasarkan apa yang telah ulama terdahulu gariskan, pendekatan psikoterapi sangat membantu untuk merawat penyakit kejiwaan yang juga boleh menyumbang kepada kesihatan pada penyakit fizikal. Usaha untuk mendapat tahap kestabilan emosi dan ketenangan jiwa memerlukan kepada konsistensi amalan dan penghayatan dalam amalan tersebut. Walaupun telah diberi

${ }^{86}$ Ibn Qayȳ̄m al-Jawziyyah, Igathāt al-Lahfān min Masāyid al-Shaitān, ed. Muhammad Sayȳ̄d Kailaniy (Kaherah: Musțafā al-Bābiy al-Ḥalabiy, 1991), $1: 83$.

87 Ibn Qayȳim al-Jawziyyah, al-Tibyān fi Aqsām al-Qur'ān (Beirut: Dār alMa'rifah, t.t.), 415.

${ }^{88}$ Ibn Qayyīm al-Jawziyyah, al-Tibyān fi Aqsām al-Qurān, 415. Zulkiflee bin Haron, 'Konsep al-Shifa' dalam al-Qur'an : Kajian Terhadap Metode Rawatan Ibn Qayyim Al-Jawziyyah" (Tesis Kedoktoran, Universiti Malaya, 2016), 138.

${ }^{89}$ Ibn Qayyim al-Jawziyyah, Zād al-Ma'ād fi Hadyi Khayr al-'Ibād, 248.

90 Ibn Qayyim, Zād al-Ma 'àd fi Hadyi Khayr al-'Ibād, 209.

91 Ibn Qayyim, Igathāt al-Lahfān min Masāyid al-Shaitān, 1:71-72.

92 Ibn Qayyim, Zād al-Ma 'àd fi Hadyi Khayr al-'Ibād, 208-209. 
pelbagai cadangan amalan yang perlu dilakukan, seseorang itu perlukan pengorbanan terhadap sesuatu yang bersifat kehendak dan kepuasan diri semata-mata. Hati yang tidak tunduk kepada suatu yang bersifat keduniaan akan lebih mudah untuk mendapat ketenangan yang hakiki walaupun ditimpa dengan pelbagai ujian kehidupan.

Walau bagaimanapun, pendekatan ini memerlukan kepada panduan khusus agar mudah untuk diikuti oleh orang awam. Penghasilan panduan ini memerlukan usaha yang jitu bagi menghasilkan satu modul khusus untuk membantu memudahkan pesakit mengikuti apa yang disarankan untuk diamalkan. Di samping itu juga memerlukan kepada usaha untuk melahirkan ahli terapi yang boleh mengendalikan terapi bagi membimbing pesakitpesakit kronik tersebut dengan cara terbaik dan berkesan.

\section{Rujukan}

'Abd al-Karīm, Abī 'Abd al-Raḥman Nu'man bin. Al-Watr alNabī Muhammad (Iskandariah: Dār al-Īmān, 2008), 35.

'Abd al-Salām, Zahran Ḥāmid. Al-Tawjih wa Irshād al-Nafs. Kaherah: 'Alam al-Kutub, t.t.

Ade Tis'a Subarata, "Perspektif al-Quran tentang Musibah "Telaah Tafsir Tematik tentang Ayat-ayat Musibah". Disertasi, Universitas Islam Negeri Syarif Hidayatullah, 2011.

Al-Bukhārī, Muḥammad bin Ismā‘ñl, Muhị al-Dīn Khāțib, Muhammad Fū'ad 'Abd al-Bāqī, Al-Jāmi' al-Ṣaḥịh. Kaherah: al-Matba'ah al-Salafiyah, 1979.

Al-Fayyumī, Aḥmad bin Muḥammad bin 'Alī al-Muqrī. AlMisbāh al-Munir. Beirut: al-Maktabah al-'Ilmiyyah, t.t.

Al-Ghazālī, Abū Ḥāmid Muḥammad Ibn Muḥammad. Ihyā' 'Ulum al-Dīn. Beirut: Dār al-Kutub al-'Ilmiyyah, 2001.

Al-Ghazālī, Abū Ḥāmid Muḥammad Ibn Muhammad. Majmu 'ah Rasā'il al-Imām al-Ghazālī, "Rawḍh al-Tālibīn wa 'Umdah al-Sālikīn”. Beirut: Dār al-Kutub al-'Ilmiyyah, 1986), 2:109.

Al-Ghazali. Ihya' 'Ulum al-Din, Terj.TK.H. Ismail Yakub.. Singapura: Pustaka Nasional, 1998.

Al-Jawziyyah, Ibn Qayyīm. Al-Da 'wā aw al-Jawāb al-Kāfí li Man Sa'ala 'an al-Da 'wā' al-Shäfì. Mansoura: Dār al-Khulafā' li alNashr wa al-Tawzī', 1994. 
Al-Jawziyyah, Ibn Qayyīm. Al-Tibyān fi Aqsām al-Qur'ān. Beirut: Dār al-Ma'rifah, t.t.

Al-Jawziyyah, Ibn Qayyīm. Igathāt al-Lahfān min Masāyid alShaitān, ed. Muhammad Sayyīd Kailaniy. Kaherah: Musțafā alBābiy al-Halabiy, 1991.

Al-Jawziyyah, Ibn Qayyìm. Zād al-Ma 'ād fì Hady Khayr al-'Ibād, tahqiq, takhrij dan ta'liq oleh Shu'ayb dan 'Abd al-Qādir alArnaūt. Beirut: Muassasah al-Risālah, dan Maktabat al-Manār al-Islāmiyyah, 1992.

Al-Mandili, Penawar Bagi Hati. Yala: Sahabat Press, 1964.

Al-Mawardī, Abū Haasan 'Alī ibn Muhammad. Kitāb Adāb alDunyā wa al-Dīn. Beirut: Dār Maktabah al-Hayāh, 1986.

Al-Mubārakfurī, Safì al-Raḥman. al-Rahiq al-Makhtum. Riyadh: Dār al-Salam li al-Nashr wa al-Tawzi', 2004.

Al-Ṭabarī, Ab̄̄ Ja'far Muhammad bin Jarīr. Tafsīr al-Tabarī. Kaherah: Markaz al-Buhuth wa al-Dirāsāt al-'Arabiyyah alIslāmiyyah, 2001.

Azizi Yahya. Psikologi Abnormal. Skudai: UTM Press, 2007.

Buzan, Tony, The Power of Spiritual Intelligence. London: Thorsons, 2001) h.xiii. Rujuk Khālid 'Abd al-Raḥman, Tarbiyyah al-Abnā' wa al-Banāt fì Daw' al-Qur'ān wa alSunnah. Beirut: Dār al-Ma'rīfah, 2005.

Che Zarrina, "A Purification of Soul According to Sufis : A Study of Al-Ghazali's Theory," Jurnal AFKAR 3 (2002), 100-101.

Chiara Renzi, Valeria Vadilonga dan Sara Gandini, "Stress Exposure in Significant Relationships is Associated with Lymph Node Status in Breast Cancer", laman sesawang Relational Stress in Breast Cancer dicapai February 24, 2016, DOI:10.1371/journal.pone.0149443.

DRS. H. Abdullah Hadziq, MA, "Psikologi Sufistik dan Humanistik: Studi Pemikiran Al-Ghazali dan Abraham Maslow Serta Implikasinya bagi Pengembangan Pemikiran Psikologi”. Yogyakarta: Program Pascasarjana IAIN Sunan Kalijaga, 2004.

Drs. Untung Joko Basuki. M. Pd. I, "Psikoterapi Islam Melalui Metode Sufistik Mengatasi Gangguan Kejiwaan”. Laporan Penelitian, Yokyakarta, Fakultas Teknologi Industri Institut Sains dan Teknologi. AKPRIND, 2013. 
Entri "hyperarousal", laman sesawang The Free Dictionary, dicapai 15 Ogos 2018, https://medical-dictionary.thefreedictionary .com/hyperarousal.

Gibson, R.L dan Mitcheel M.H, Introduction to Guidance. New York: Michillan Publishing. Co. Inc. 1981.

Hadith riwayat al-Bukhārī, Hadith Nombor 5640. Lihat Muḥammad bin Ismā'îl al-Bukhārī, Șaḥ̄ḥ al-Bukhārī li-Abī 'Abd Allāh Muhammad bin Ismā'īl al-Bukhārī al-Ju'fì. Riyadh: Dār al-Salām, 1999.

Hairunas Rejab, "Psikoterapi Islam dan Pengaplikasiannya dalam Kesihatan Mental". Tesis Kedoktoran, Universiti Malaya, 2006. Hofman, Maarten, Julie L. Ryan, Colmar D. Figueroa-Moseley, Pascal Jean-Pierre, dan Gary R. Morrow. "Cancer-related fatigue: the scale of the problem". The Oncologist 12, no. Supplement 1 (2007), 4-10.

Hofman, Maarten, Julie L. Ryan, Colmar D. Figueroa-Moseley, Pascal Jean-Pierre, and Gary R. Morrow. "Cancer-related Fatigue: the Scale of the Problem, 4-10."

Http://citeseerx.ist.psu.edu/viewdoc/download;jsessionid=B117B A0DF1B3F19CD3CD43A90279DCAB?doi=10.1.1.510.3556\& rep=rep1\&type $=$ pdf dicapai pada 20 Februari 2016.

Ibn Manzūr, Muhammad ibn Mukarram ibn 'Alī ibn Ahmad. Lisān al-'Arab. Beirut: Dār Ihyā’ al-Turath al-'Arabī, 1999.

Ibn Miskawayh, Abū 'Al̄̄ Aḥmad ibn Muḥammad ibn Ya'qūb.

Tahdhīb al-Akhlāq. Beirut: Dār Maktabah al-Ḥayāh, t.t.

Jahid Sidek. Shaikh dalam ilmu Tariqah. Kuala Lumpur: Universiti Malaya, 1997.

Jie Li, Lixiang $\mathrm{Yu}$, Zhouting Long et al, "Perceived Cognitive Impairment in Chinese Patients with Breast Cancer and its Relationship with Post-Traumatic Stress Disorder Symptoms and Fatigue", Psycho-Oncology 24 (2008), 676-682. DOI: 10.1002/pon.

Jones, Arthur J. Principles of Guidance. New York: McGraw-Hill Book Company, 1970.

Khairul Hamimah Mohammad Jodi, Mohd Afifuddin Mohamad, dan Azizi Che Seman, "Penerapan Agama dalam Modul Psikospiritual dan Kesannya Terhadap Kesihatan Spiritual: Kajian Kes Kompleks Dar Assaadah Kuala Lumpur", Jurnal Syariah Malaysia (2014). 
Khalid, Khalid Muhammad. Men Around the Messenger. Kuala Lumpur: Islamic Book Trust, 2005.

Khālid, Khālid Muḥammad. Rijāl Hawl al-Rasūl. Kaherah: Dār alKutub al-Hadīthah. 1968.

M Amin Syukur, "Sufi Healing: Terapi dalam Literatur Tasawuf" 20, no. November (2012): 391-412.

Masuriyati Yahya dan Che Zarrina Sa'ari, "Program Zikrullah dan Aktiviti Kerohanian Asas Pembangunan Spiritual Golongan Belia Perlu Perhatian (PP) dalam Merealisasikan Gagasan Negara Zikir Brunei Darussalam”, GJAT 6, no. 1 (2016): 109.

Mohamad Abu Bakar. "Islam Sebagai Budaya dan Peradaban: Ke mana? Dimana?", Jurnal Pemikir 39\&40 (2005), 271-282.

Mohamad Kamil Abd Majid dan Rahimin Affandi Abd Rahim, "Perubahan Sosial dan Impaknya Terhadap Pembentukan Modal Insan Menurut Ibn Khaldun", Jurnal Hadhari 1 (2009), 45-76.

Mohammad Zaini Yahaya dan Mohd Sukki Othman, Mengurus Stres: Islam Ada Caranya. Selangor: Soul Excellent Training \& Consultancy, 2010.

Muhammad Mahmud Rabie', The Political Theory of Ibn Khaldun. Leiden: E. J. Brill, 1967.

Muhammad Uthman Najati. Psikoterapi Menurut al-Quran, terj Abd. Rahman. Selangor: Human Resource Enterprise, 1992.

Muhammad Yasin Mazhar. Organisasi Kepimpinan Rasulullah, terj Mohd Khalil Mad Zain dan Md Yusof Md Said. Kuala Lumpur: Dewan Bahasa dan Pustaka, 1993..

Mustafa Al-Bugha dan Muhyiddin Misto, Al-Wafi Syarah Hadith 40 Imam Nawawi, terj. Ahmad Khairi Al-Latifi dan Noraine Abu. Kuala Lumpur: Al-Hidayah Publishers., 2007.

Nāsih 'Ulwān, 'Abd Allāh. Kayf Yad'u al-Dā'iyyah. Beirut: Dār al-Salām, 1985.

Nik Asilah Nik Ali. "Rawatan Kaunseling Terhadap Penagih Dadah di Rumah Pengasih Kuala Lumpur: Suatu Kajian Perbandingan dengan Islam". Kuala Lumpur: Universiti Malaya, 2002.

Nor Shakirah Binti Azizan, "Isqat Al-Tadbir dalam Kitab Tanwir Al-Qulub fi Isqat Tadbir Al-'Uyub Terjemahan 'Uthman Shihab Al-Din Al-Funtiani”. Akademi Pengajian Islam Universiti Malaya: Jabatan Akidah dan Pemikiran Islam, 2015. 
Norfadilah Abdul Rahman dan Zakaria Stapa. "Pembangunan Kerohanian Berasaskan Al-Muhasibi dalam Menangani Gejala Sosial Masa Kini". Proceeding of the International Conference on World Conference of Integration Knowledge, Bandung, Indonesia, 15-16 September 2014.

Nurdeng Deuraseh. Preservation of Health in Islamic Law. Kuala Lumpur: International Islamic University Malaysia: IIUM Press, 2009.

Pangastiti, Nuuferulla Kurniantyas dan Mudji Rahardjo, “Analisis Pengaruh Dukungan Sosial Keluarga Terhadap Burnout Pada Perawat Kesehatan di Rumah Sakit Jiwa (studi pada RSJ Prof Dr Soeroko Magelang)". Tesis Kedoktoran, Universitas Diponegoro, 2011.

Rainbow T. H. Ho, Tracy T. C. Kwan, Irene K. M. Cheung, et al, "Association of Fatigue with Perceived Stress in Chinese Women with Early Stage Breast Cancer Awaiting Adjuvant Radiotherapy", Stress Health 31 (2015), 214-221.

S. Mohamed Hatta. Psikologi dan Kaunseling Remaja. Selangor: Ummah Media Sdn. Bhd., 1994.

Salasiah Hanin Hamjah, "Pendekatan Da'wah Al-Irsyad AlNafsiyy Menurut Al-Ghazali: Satu Kajian di Pusat Kaunseling Majlis Agama Islam Negeri Sembilan" (Tesis Kedoktoran, Universiti Kebangsaan Malaysia, 2008).

Sayyid Qutb, "Terjemahan Tafsir fī Zilālil Quran", Surah alMa'ārij, laman sesawang Tafsir fi Zilalil Quran, dicapai pada 16 Ogos 2018, https://tafsirzilal.files.wordpress.com/2015/04/almaarij-melayu.pdf.

Schultz, Duane P dan Schultz Sydney Ellen, Theories of Personality. USA: ThomsonWadsworth, 2005.

Sharifah Basirah Syed Muhsin dan Che Zarrina Sa'ari, Kaedah Psikoterapi Islam berdasarkan Konsep Maqamat Abu Talib alMakki. Kuala Lumpur: Dewan Bahasa dan Pustaka, 2015.

Siti Noorsyafenas Safe dan Ahmad Yunus Mohd Nor, "Pengurusan Stress Menurut Al-Quran dan Hadith", Jurnal alHikmah 8 (1) 2016, 3-18.

Siti Sarah Haji Ahmad. "Adāb al-Riyāḍah wa Al-Istislah dalam Pembangunan Modal Insan Menurut al-Mawardī dalam Karya Adāb al-Dunya wa al-Dīn". Disertasi, Jabatan Akidah dan Pemikiran Islam, Universiti Malaya, 2014. 
Sri Astutik, "Psikoterapi Islami dalam Mengatasi Ketergantungan Narkoba di Pondok Pesantren Inabah Surabaya". Doktor Pasca Sarjana (IAIN Sunan Ampel, Surabaya, 2011).

Sri Nyumirah. Pengaruh Terapi Perilaku Kognitif Terhadap Kemampuan Interaksi Sosial Klien Isolasi Sosial di RSJ DR Amino Gondohotumo Semarang. Indonesia: Universitas Indonesia Depok, 2012.

Syed Mohammad Hilmi Syed Abdul Rahman dan Che Zarrina Sa'ari, "Kesan Kefahaman Konsep Takdir Terhadap Pembangunan Modal Insan" Jurnal Usuluddin 27 (2008), 1-23.

Thouless, Robert H. "Experiments on paranormal guessing", British Journal of Psychology, British Psychological Society 33, no. 1 (1942).

Tso-Ying Lee, Hsing-Hsia Chen dan Mei-Ling Yeh, "Measuring Reliability and Validity of a Newly Developed Stress Instrument: Newly Diagnosed Breast Cancer Stress Scale", Journal of Clinical Nursing 22 (2013), 2417-2425, Doi: 10.1111/jocn.12107.

Wan Suhaimi Wan Abdullah dan Che Zarrina Sa'ari eds., "Tasawwuf dan Pembangunan Hakiki Ummah", Tasawwuf dan Ummah. Kuala Lumpur: Jabatan Akidah dan Pemikiran Islam, Akademi Pengajian Islam, 2004.

Yatimah Sarmani dan Mohd Tajudin Minggal, Teori Kaunseling Al-Ghazali, Mengenal Ilmu, Sejarah dan Kandungan Al-Quran. Batu caves: PTS Publication, 2008.

Zaenal Abidin, "Ketika Stress Beraksi Islam Punya Solusi", Jurnal Dakwah dan Komunikasi 3 No 1 (2009), 148-166.

Zaizul Ab. Rahman, Indriaty Ismail dan Khaidzir Ismail. "Strategi Modul Pembangunan Insan Seimbang Pengajian Agama (PISPA) Berdasarkan Teori Perubahan Sosial Ibnu Khaldun dalam Pengajian Agama di Universiti Kebangsaan Malaysia”, Jurnal Al-Hikmah 6 (2) 2014: 43-52.

Zulkiflee bin Haron, 'Konsep al-Shifa' dalam al-Qur'an: Kajian Terhadap Metode Rawatan Ibn Qayyim Al-Jawziyyah". Tesis Kedoktoran, Universiti Malaya, 2016.

Zulkiple Abd. Ghani dan Nor Salimah Abu Mansor. "Penghayatan Agama Sebagai Asas Pembangunan Pelajar: Analisis Terhadap Beberapa Pandangan Al-Imam Al-Ghazali”, laman sesawang Universiti Teknologi Malaysia Institutional Repository, dicapai 
pada 20 Februari 2016, http://eprints.utm.my/id/eprint/375/1 /ZulkipleAbdGhani2006_Penghayatanagamasebagaiasaspemba ngunan.pdf. 